\title{
Distribution and fate of aliphatic and aromatic hydrocarbons in Antarctic fauna and environment
}

\author{
H. M. Platt ${ }^{1}$ \& P. R. Mackie ${ }^{2}$ \\ ${ }^{1}$ British Antarctic Survey; Cambridge, England, * \\ and \\ ${ }^{2}$ Torry Research Station, Aberdeen, Scotland
}

\begin{abstract}
With the depletion of oil resources in more accessible areas, those of remote regions are being considered or indeed are now being exploited. In many of these regions, especially the polar ones, little is known of the effects such exploitation will have on the environment. But it is known that the ecosystems are often subject to great stress by natural climatic conditions and additional burdens imposed by man may have catastrophic environmental effects. South Georgia, a sub-Antarctic island, has a history of industrial activity mainly concerned with whaling operations that peaked around 1925-1935 but has since declined to virtually nothing. Studies of the ecology of the area provided a unique opportunity to assess the long-term effects that such activities had on the ecosystem. Off the whaling stations a considerable amount of waste material, including fuel oil, was released into the bays and inevitably some of this material was deposited in the sediments. Chemical evidence in the form of both paraffinic and aromatic hydrocarbons still persists in the sediments. The implications of this persistence in relation to the possible influence of the low temperature conditions are discussed. The superficial sediments, marine biota and terrestrial plants, which since 1965 have returned virtually to a pristine state, contain hydrocarbons essentially similar to unpolluted areas around the coast of Britain. Relatively high levels of carcinogenic/ mutagenic polynuclear aromatic hydrocarbons in surface sediments suggests a world-wide background of abiogenic hydrocarbons probably disseminated by airborne transport. This appears to indicate that contamination reaches even remote parts of the world in relatively undiminished quantities.
\end{abstract}

\section{INTRODUCTION}

The increasing concern over the finite nature of non-renewable resources, recently highlighted by the current problems in the Middle East and their concomitant effects on world oil supplies and prices, has logically focused attention on reserves in the more remote regions of the globe. Consequently, several nations are now actively seeking to exploit the mineral stocks thought to be present in Antarctica. The effects that any large scale exploitation would have on the relatively pristine polar ecosystem are not known, although some work has been carried out on the fate and effects of oil in a cold marine environment in connection with the North Alaskan oilfields (Atlas et al., 1978). However, an awareness of these problems in relation to Antarctica has been evidenced by a number of recent discussions (Cole, 1979). But it must always be borne in mind that the dangers and repercussions of spills in Antarctica are potentially much greater than in

* Present address: British Museum (Natural History), Cromwell Road, London, SW 7 5BD, England 
northern polar regions because of the former's greater remoteness and hence a lack of public awareness likely to press for conservation measures.

Although many data exist on the alkane content and composition of various components of temperate marine ecosystems there is as yet little known about their polynuclear aromatic hydrocarbons (PAHs), whilst for polar regions information is lacking on all aspects of the presence, fate and effects of oil. This paper reports work on the presence and fate of hydrocarbons in the cold, remote marine Antarctic ecosystem of South Georgia, an island in the Atlantic sector of the Southern Ocean, described more fully by Mackie et al. (1978a). In addition, the persistence of hydrocarbons was examined by analysis of deep core sections from the sea bed of a disused whaling station (Grytviken). It is hoped that this study will stimulate further research.

\section{MATERIALS AND METHODS}

Sampling was carried out in 1974 and 1975 from King Edward Cove and its environs. Extreme care was taken to avoid contamination of the samples, which were deep-frozen for analysis in the United Kingdom. The analytical techniques have been extensively described elsewhere (Mackie et al., 1974, 1978a, b). Essentially, aliphatic hydrocarbons were determined by solvent extraction, column chromatographic isolation and glasscapillary gas chromatography (GC); PAHs were determined on the same extracts after isolation according to Giger \& Schaffner (1978), slightly modified to remove the large quantities of sterol found in some organisms, and analysed by glass-capillary GC/MS (Mackie et al,, 1978b).

\section{RESULTS}

The alkanes of five of the most common land plants, a soil sample and a freshwater core (Table 1) were analysed as being typical of what the land and freshwater runoff might contribute in terms of hydrocarbon input to the marine environment.

The land plants appear to fall into three groups: (1) the moss with its relatively low total alkane and high pristane levels; (2) the burnet with a high total alkane content, exceptionally high carbon preference index (CPI - a measure of odd-carbon chain length alkane predominance over even-carbon chain length alkanes, where equal proportions of each give a CPI of one) and no pristane; (3) the rush and grasses which had intermediate values. The soil and freshwater sediments are essentially similar, but since the primary source of their hydrocarbons appears to be the land plants, considerable chemical changes must take place en route from growing plant to soil or sediment in order to lower the CPI, by an order of magnitude. Perhaps a herbivore is involved? The mechanism(s) of such change is a tempting subject for further study.

The only marine plant examined, the kelp (Macrocystis pyrifera), has a completely different suite of aliphatic hydrocarbons (Table 1) compared with the terrestrial flora, with pentadecane (n-C 15) accounting for over $90 \%$ of its total alkanes (Fig. 1).

The other marine organisms investigated were a mixed zooplankton sample, selected benthos species, krill (Euphausia superba) and three common fish (plus a seawater sample). In general, their component hydrocarbons (Table 2) are qualitatively and quantitatively similar to comparable samples from temperate northern hemisphere areas 

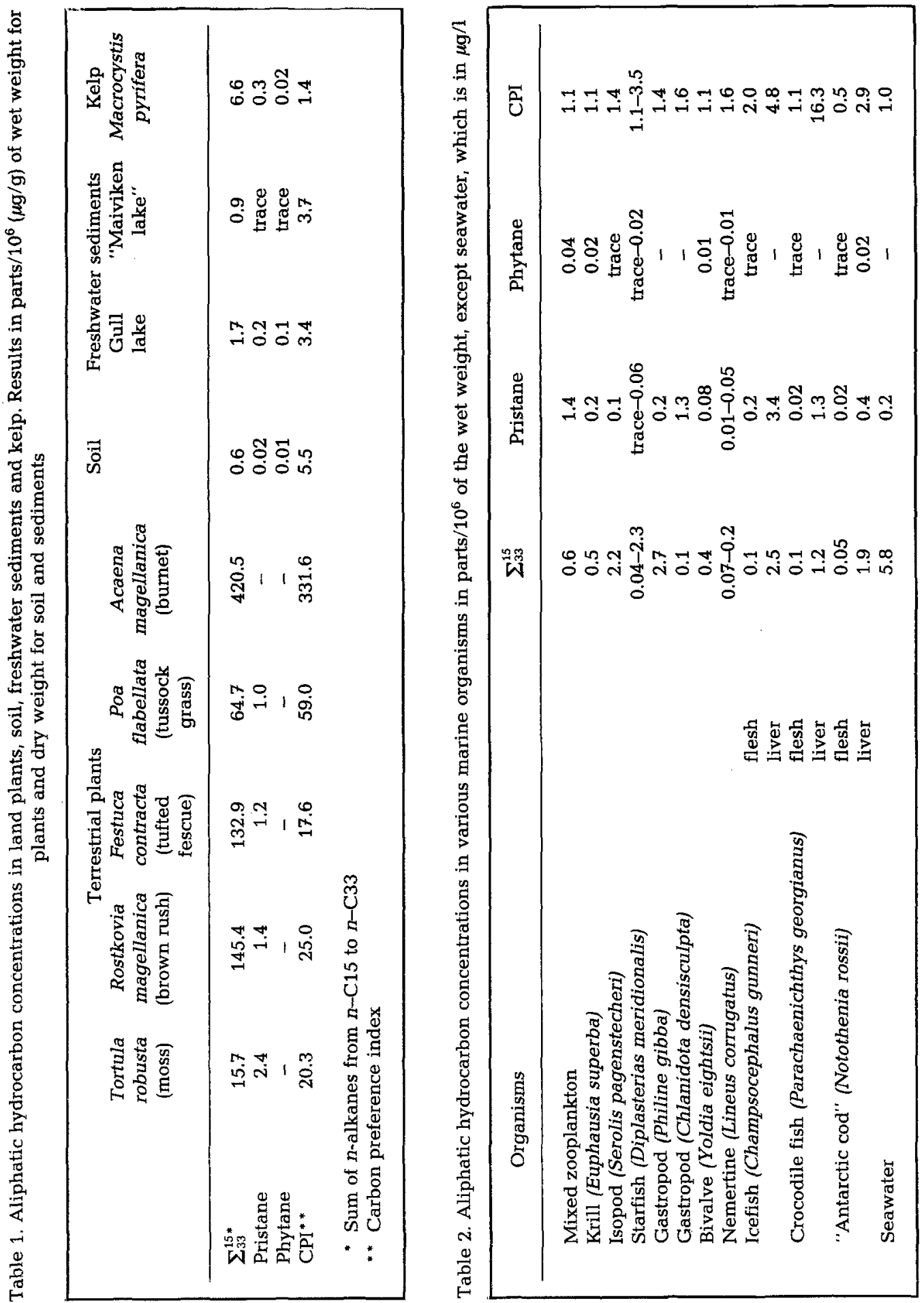


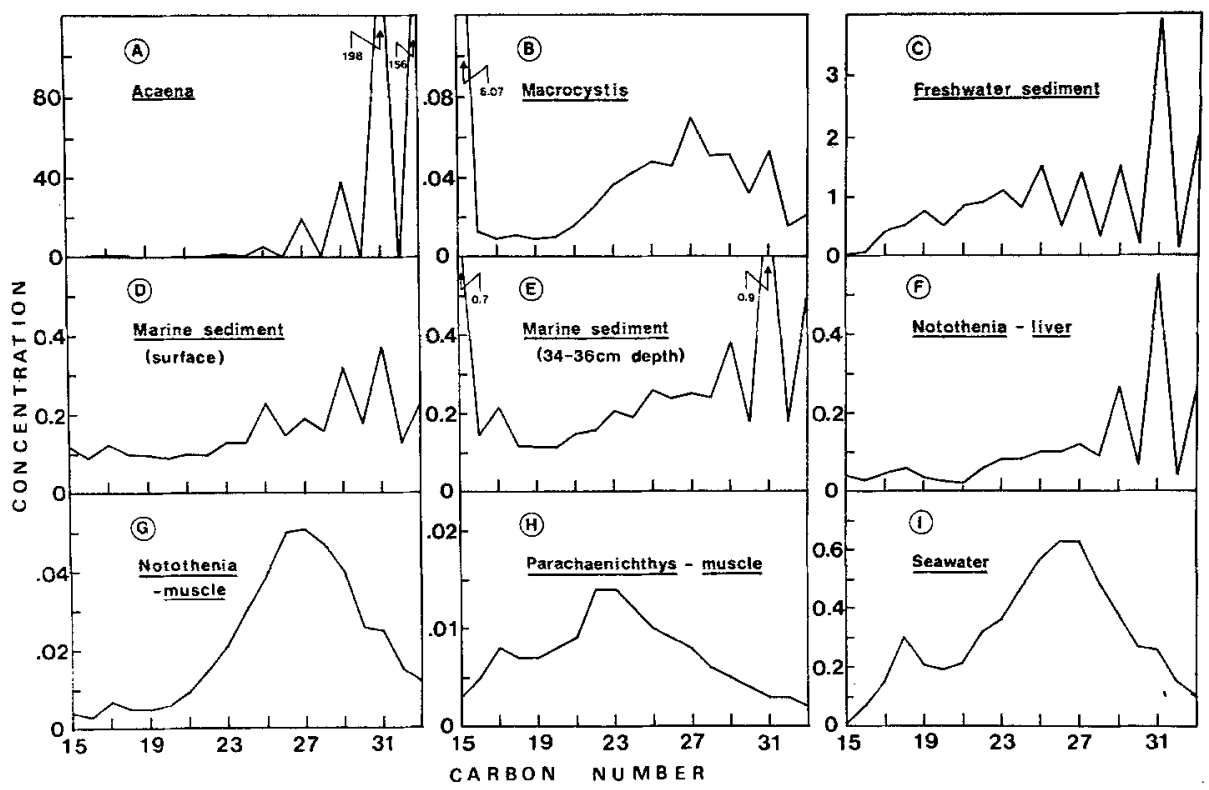

Fig. 1. n-Alkane distributions in various components of the King Edward Cove ecosystem. Concentration is in parts $/ 10^{6}$ of the fresh/wet weight for biota, parts $/ 10^{6}$ of the dry weight for sediment and $\mu \mathrm{g} / \mathrm{l}$ for seawater

(Corner et al., 1976; Whittle et al., 1977). However, the PAH composition of the fish, whilst qualitatively similar, appears to be rather reduced in amounts when compared with herring and mackerel from the North Sea (Table 3).

Surface sediments sampled at various points within and outside the Cove gave the alkane values quoted in Table 4. Again, the values are similar to those obtained from the northern hemisphere. However, a sectioned 36- $\mathrm{cm}$ long core showed that considerable changes in the inputs of both paraffinic (Table 5) and aromatic (Table 6) hydrocarbons had occurred over the last 80 years or so. The means by which the sediments were dated (sediment trap experiments and organic profiles) were reported by Platt (1979).

\section{DISCUSSION}

Crude oil and the various fuels derived from it are complex mixtures which cannot easily be analysed per se. The usual approach is either to analyse for a single substance or group of substances (such as alkanes or PAHs) or to examine for a specific property such as fluorescence and extrapolate the data back to "crude oil units" via a standard oil. Such a treatment of results, however, assumes that the spilt oil is unchanged. Since this is never the case, because of both physical and chemical changes, the results reported. here relate to specific compounds and hence can only be used as indicators and not as a measurement of oil. The various component parts of King Edward Cove's ecosystem were examined from this point of view.

Any discussion of the hydrocarbon compositions found in King Edward Cove must take account of the past history of the bay. In 1904 the first of the great land-based 


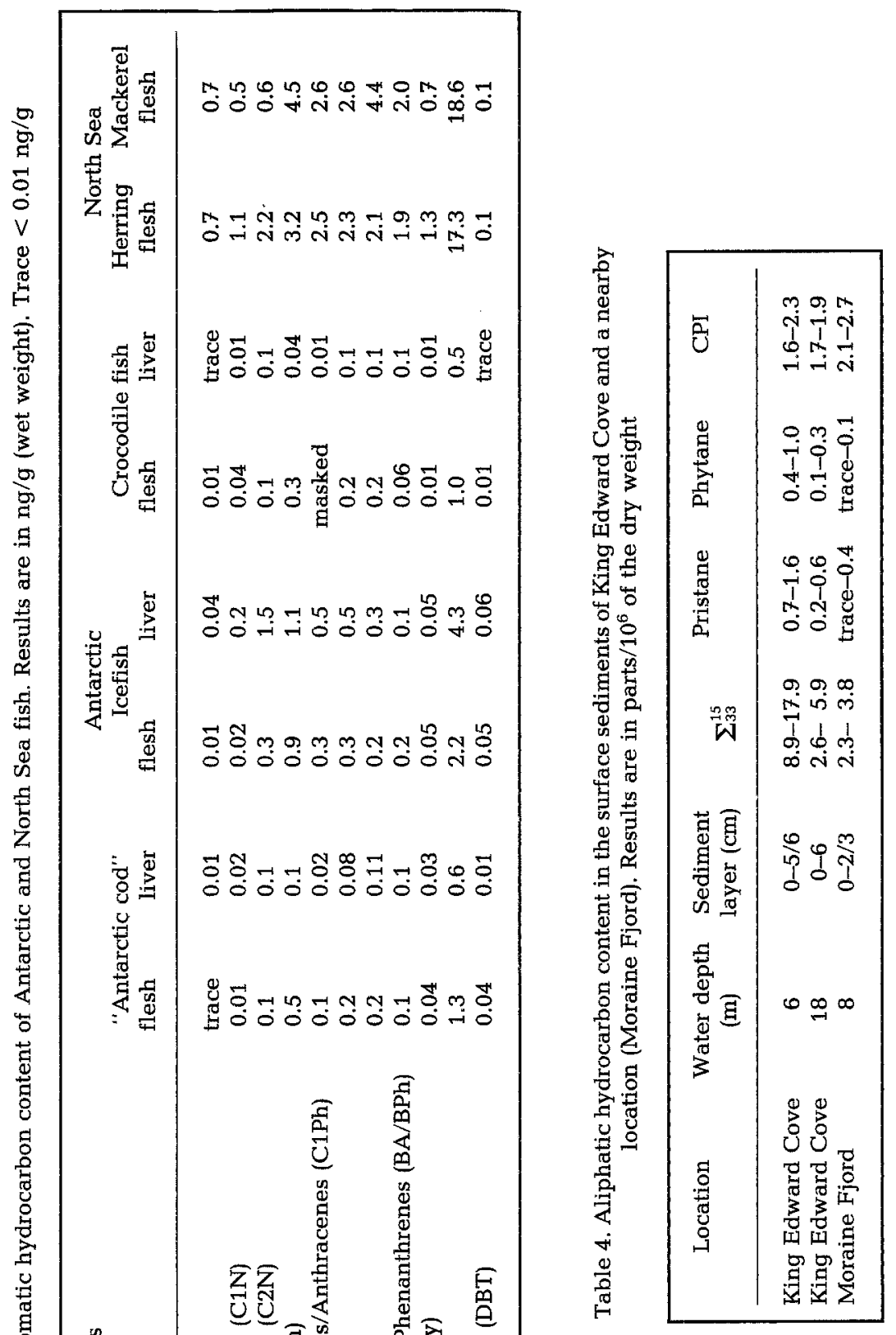


Table 5. Aliphatic hydrocarbon content of a $36 \mathrm{~cm}$ long sediment core from the centre of King Edward Cove. Results are in parts $/ 10^{6}$ of the dry weight. The dating refers to the approximate year when that layer began to be laid down

\begin{tabular}{|cccccc|}
\hline $\begin{array}{c}\text { Sediment } \\
\text { layer (cm) }\end{array}$ & $\begin{array}{c}\text { Approximate year } \\
\text { of deposition }\end{array}$ & $\sum_{33}^{15}$ & Pristane & Phytane & CPI \\
\hline $0-1.5$ & 1973 & 3.1 & 0.2 & 0.1 & 1.7 \\
$1.5-2.5$ & - & 2.7 & 0.2 & 0.1 & 1.6 \\
$2.5-3.5$ & - & 1.6 & 0.1 & trace & 2.1 \\
$3.5-6$ & 1964 & 2.7 & 0.3 & 0.1 & 1.5 \\
$6-8$ & - & 4.8 & 0.2 & 0.2 & 1.3 \\
$8-10$ & - & 6.3 & 0.2 & 0.1 & 1.1 \\
$10-12$ & 1950 & 3.8 & 0.5 & 0.3 & 1.2 \\
$12-14$ & - & 5.0 & 0.5 & 0.3 & 1.6 \\
$14-16$ & - & 3.9 & 0.4 & 0.2 & 1.6 \\
$16-18$ & 1935 & 2.2 & 0.4 & 0.1 & 1.7 \\
$18-20$ & - & 2.8 & 0.5 & 0.1 & 1.6 \\
$20-22$ & - & 2.2 & 0.6 & 0.1 & 1.7 \\
$22-24$ & 1920 & 1.6 & 0.6 & 0.1 & 1.9 \\
$24-26$ & - & 4.3 & 1.1 & 0.1 & 1.5 \\
$26-28$ & - & 4.5 & 2.5 & 0.2 & 1.4 \\
$28-30$ & 1904 & 3.6 & 9.2 & 0.1 & 1.7 \\
$30-32$ & - & 8.8 & 3.6 & 0.1 & 1.6 \\
$32-34$ & - & 6.9 & 5.0 & 0.1 & 1.5 \\
$34-36$ & 1886 & 5.3 & 2.4 & 0.1 & 1.9 \\
\hline
\end{tabular}

Table 6. Aromatic hydrocarbon content of a $36-\mathrm{cm}$ long sediment core from the centre of King Edward Cove. Results are in ng/g (dry weight). See Table 3 for abbreviations. Trace $=0.1-0.4 \mathrm{ng} / \mathrm{g}$

\begin{tabular}{|c|c|c|c|c|c|c|c|c|c|c|c|}
\hline $\begin{array}{l}\text { Sediment } \\
\text { layer }(\mathrm{cm})\end{array}$ & $\mathbf{N}$ & C1N & $\mathrm{C} 2 \mathrm{~N}$ & $\mathrm{Ph}$ & $\mathrm{C} 1 \mathrm{Ph}$ & Fl & Py & $\mathrm{BA} / \mathrm{BPh}$ & BPy & $\Sigma \mathrm{PAH}$ & DBT \\
\hline $\begin{array}{lll}0 & -1.5\end{array}$ & 22 & 35 & 20 & 17 & 2 & 6 & 4 & 5 & 3 & 115 & trace \\
\hline $1.5-2.5$ & 2 & 3 & 10 & 21 & 2 & 13 & 11 & 9 & 9 & 79 & trace \\
\hline $2.5-3.5$ & 7 & 8 & 20 & 27 & 2 & 12 & 12 & 11 & 6 & 105 & trace \\
\hline $3.5-6$ & 2 & 5 & 11 & 10 & 27 & 14 & 16 & 9 & 5 & 97 & trace \\
\hline $6-8$ & 17 & 17 & 35 & 34 & 90 & 31 & 34 & 35 & 13 & 307 & 3 \\
\hline $8-10$ & 10 & 11 & 22 & 9 & 6 & 7 & 10 & 9 & 2 & 84 & 1 \\
\hline $10-12$ & 2 & 5 & 13 & 5 & 4 & 3 & 5 & 8 & 2 & 45 & 1 \\
\hline $12-14$ & 13 & 28 & 55 & 75 & 36 & 98 & 145 & 144 & 70 & 662 & 8 \\
\hline $14-16$ & 5 & 14 & 31 & 68 & 12 & 77 & 102 & 152 & 40 & 500 & 4 \\
\hline $16-18$ & 6 & 19 & 26 & 72 & 12 & 41 & 41 & 79 & 25 & 321 & 3 \\
\hline $18-20$ & 13 & 17 & 25 & 42 & 5 & 29 & 38 & 45 & 23 & 238 & 1 \\
\hline $20-22$ & 20 & 55 & 89 & 50 & 22 & 47 & 41 & 47 & 14 & 384 & 4 \\
\hline $22-24$ & 13 & 10 & 13 & 157 & 5 & 137 & 100 & 36 & 38 & 510 & 1 \\
\hline $24-26$ & 14 & 12 & 15 & 41 & 3 & 47 & 41 & 18 & 10 & 199 & trace \\
\hline $26-28$ & 20 & 26 & 40 & 22 & 3 & 12 & 5 & 9 & 4 & 142 & 1 \\
\hline $28-30$ & 23 & 35 & 34 & 182 & 6 & 75 & 53 & 30 & 9 & 447 & 1 \\
\hline $30-32$ & 20 & 21 & 37 & 33 & 22 & 13 & 10 & 7 & 8 & 170 & 3 \\
\hline $32-34$ & 44 & 59 & 93 & 220 & 34 & 174 & 138 & 84 & 41 & 885 & 6 \\
\hline $34-36$ & 74 & 85 & 112 & 50 & 28 & 110 & 61 & 106 & 45 & 672 & 1 \\
\hline
\end{tabular}


Antarctic whaling stations (Grytviken) was founded at the head of the Cove. Although now abandoned, throughout its period of activity considerable quantities of organic material, fossil fuels and combustion products entered the environment. The factory finally closed after the 1964/5 season and the area has since returned to light use, with a small scientific station being visited by occasional research and, more recently, fishing vessels. Although the living system was heavily polluted in the past (Platt, 1978) it now seems to have returned to a condition (with regard to pollution) almost the same as that obtaining in apparently pristine regions of the Southern Ocean.

A considerable number of surveys and analyses of paraffinic hydrocarbons have now been carried out on various parts of temperate water ecosystems (Clark \& Blumer, 1967; Farrington \& Quinn, 1973; Whittle et al., 1974; Wakeham, 1976). If the values obtained from obviously polluted areas are discounted, it is clear that the content and composition of alkanes determined on these surveys are very similar to those found in the present study.

The composition of the alkanes is also similar in that the land plants, soils, aquatic sediments and fish livers all possess the characteristic marked odd-carbon predominance (Fig. 1, A-F) whilst fish muscle and seawater alkanes follow a relatively smooth, almost gaussian distribution peaking usually in the $n-C 26$ region (Fig. 1, G-I) (Mackie et al., 1974; Whittle et al., 1977).

Virtually no data are available for the PAH content of living systems of any area, since only now are techniques and equipment becoming available to determine the complex array of these compounds present in tissues and sediments. Apart from the unpublished data on herring and mackerel given in Table 3, the only data on PAHs of living tissues we could find are figures for benz(a)pyrene content of fish flesh (Mallet et al., 1963; Lee et al., 1972), the most relevant of these being perhaps the value of $1.5 \mathrm{ppb}$ obtained for Greenland cod (Gadus morhua) by Mallet et al. (1963). Thus, the values found in the Antarctic fish would appear to be an order of magnitude less than those of mackerel, herring and cod from the northern hemisphere, all of which show a remarkable agreement.

Crude oil, whether from spillages or natural seepages, appears to be deficient in the higher ring aromatics (Fig. 2), so it cannot be the sole source of the PAHs found. The aromatic fraction of natural seep oil resembles other crude oils but the $n$-alkane series are reduced (Reed \& Kaplan, 1977). Since the input of oil to the Southern Ocean is

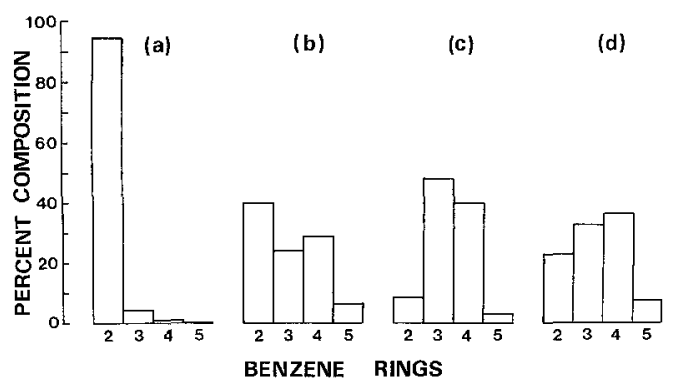

Fig. 2. Relative proportions of di-, tri-, tetra- and penta-cyclic aromatic hydrocarbons in (a) fuel oil, (b) surface marine sediment (0-3.5 cm depth), (c) "Antarctic cod" muscle and (d) herring muscle from the North Sea 
negligible when compared with Europe or North America, it is highly unlikely that the paraffinic hydrocarbons found today in the Antarctic are due to direct oil pollution. Biogenic production in the marine environment of the "smooth" array of alkanes found in "clean" seawater has not been shown (Murray \& Thomson, 1977) and their natural synthesis must be considered highly unlikely. A world-wide, low-level background of abiogenic hydrocarbons would appear to be a more likely explanation of the findings. This background could be attained either from atmospheric fallout or from the achievement of a steady-state of hydrocarbons formed by the mixing of the waters of the world's oceans. De Wiest (1978) has shown that $90 \%$ of the total mass of benz(a) pyrene in the air is associated with particles of aerodynamic diameter less than $2 \mu \mathrm{m}$, these particles having mean residence times in the air of $100+$ hours. Therefore, it would seem that a world-wide coverage of airborne hydrocarbons is a possibility. It is also tempting to speculate on whether this is the source of the ubiquitous "smooth" $n$-alkane distribution universally found in "clean" water.

Excluding the naphthalene series, the mean PAH concentration in the top $3.5 \mathrm{~cm}$ of the King Edward Cove mud (75 ppb) was eleven times less than that found in the fine sands of Buzzards Bay (Hites et al., 1977), a shallow $(17 \mathrm{~m}$ ) site near the very heavily industrialised northeastern seaboard of the USA and about half of the $160 \mathrm{ppb}$ figure for surface sediments at $130 \mathrm{~m}$ depth $94 \mathrm{~km}$ east of Boston, Massachusetts (Windsor \& Hites, 1979). Therefore, although the influence of grain size on PAH concentration must be taken into account, the concentrations found at South Georgia still seem surprisingly high for such an isolated location, indicating that global contamination reaches even remote parts of the world in relatively undiminished quantities.

Whatever the source of these compounds, the question of their persistence remains. It is well known that the n-alkanes are preferentially degraded with respect to the branched members (Burns \& Teal, 1979), but that given the right conditions and sufficient time, all will disappear. It has been established that this degradation will be slower in polar regions (Atlas et al., 1978). The presence of persistent alkanes deep in the sediment cores from King Edward Cove, some 70 years after being deposited (Platt \& Mackie, 1979), further supports the reduced rate of decomposition in these very cold conditions.

The persistence of large amounts of PAHs deep in these sediments, the result of activities at the whaling station, would appear to raise entirely different questions. Movement of aliphatic hydrocarbons into the sediment and their subsequent degradation has been noted by several workers (Burns \& Teal, 1979; Davies et al., unpublished) but it would appear that the carcinogenic/mutagenic PAHs do not behave in the same manner. Grimmer \& Böhnke (1975) found temporally constant levels of PAHs in the unpolluted end of a Swiss lake and from this inferred that no chemical or microbial degradation of the PAHs had taken place over the intervening 60 years or so. The sharp discontinuities found in the long core (Table 6), figured by Platt \& Mackie (1979), also spanning some 60 years, would appear to argue against any diffusion of PAHs. Thus, the PAHs, once shielded by sedimentation from any photo-oxidative reactions, seem to be an extremely persistent class of compounds.

In conclusion, the results of this work further substantiate the observation that the behaviour of oil and its various components is markedly influenced by temperature conditions. Consequently, pollution effects found in temperate areas cannot with safety 
be assumed to pertain in polar regions. Nor is the remote Antarctic environment immune from the effects of the global dissemination of combustion hydrocarbons from anthropogenic sources. These points should be taken fully into account when contemplating large-scale exploitation of Antarctica's resources. Further research is necessary to ascertain to what extent this unique region can adequately bear the inevitable strain of such activities.

\section{LITERATURE CITED}

Atlas, R. M., Horowitz, A. \& Bosdosh, M., 1978. Prudhoe crude oil in Arctic marine ice, water, and sediment ecosystems: degradation and interactions with microbial and benthic communities. J. Fish. Res. Bd Can. 35, 585-590.

Burns, K. A. \& Teal, J. M., 1979. The West Falmouth oil spill: hydrocarbons in the salt marsh ecosystem. - Estuar. coast. mar. Sci. 8, 349-360.

Clark, R. C. \& Blumer, M., 1967. Distribution of $n$-paraffins in marine organisms and sediment. Limnol. Oceanogr. 12, 79-87.

Cole, H. A. 1979. Antarctic minerals. - Mar. Pollut. Bull. 9, 98.

Corner, E. D. S., Harris, R. P., Whittle, K. J. \& Mackie, P. R., 1976. Hydrocarbons in marine zooplankton and fish. In: Effects of pollutants on aquatic organisms. Ed. by. A. P. M. Lockwood. Cambridge Univ. Press, Cambridge 71-105.

De Wiest, F., 1978. Any factors influencing the dispersion and the transport of heavy hydrocarbons associated with airborne particles. - Atmos. Environ. 12, 1705-1711.

Farrington, J. W. \& Quinn, J. G., 1973. Petroleum hydrocarbons in Narragansett Bay I. Survey of hydrocarbons in sediments and clams (Mercenaria mercenaria). - Estuar. coast. mar. Sci. 1, 71-79.

Giger, W. \& Schaffner, C., 1978. Determination of polycyclic aromatic hydrocarbons in the environment by glass capillary gas chromatography. - Analyt. Chem. 50, 243.

Grimmer, G. \& Böhnke, H. 1975. Profile analysis of polycyclic aromatic hydrocarbons and metal content in sediment layers of a lake. - Cancer Lett. 1, 75-84.

Hites, R. A., Laflamme, R. E. \& Farrington, J. W., 1977. Sedimentary polycyclic aromatic hydrocarbons: the historical record. - Science, N. Y. 198, 829-831.

Lee, R. F., Sauerheber, R. \& Dobbs, G. H., 1972. Uptake, metabolism and discharge of polycyclic aromatic hydrocarbons in marine fish. - Mar. Biol. 17, 201-208.

Mackie, P. R., Whittle, K. J. \& Hardy, R., 1974. Hydrocarbons in the marine environment. I. $n-$ alkanes in the Firth of Clyde. - Estuar. coast. mar. Sci. 2, 359-374.

Mackie, P. R., Platt, H. M. \& Hardy, R., 1978a. Hydrocarbons in the marine environment. II. Distribution of $n$-alkanes in the fauna and environment of the sub-antarctic island of South Georgia. - Estuar. coast. mar. Sci. 6, 301-313.

Mackie, P. R., Hardy, R. \& Whittle, K. J., 1978b. Preliminary assessment of the presence of oil in the ecosystem at Ekofisk after the blowout, April 22-30, 1977. - J. Fish. Res. Bd Can. 35, 544-551.

Mallet, L., Perdriau, L. V. \& Perdriau, J., 1963. Pollution par les hydrocarbures polybenzéniques du type benzo-3, 4-pyréne de la région occidentale de l'océan glacial Arctique. - C. r. hebd. Séanc. Acad. Sci, Paris 256, 3487-3489.

Murray, J. \& Thomson, A., 1977. Hydrocarbon production in Anacystis montana and Botryoccocus braunii. - Phytochemistry $16,465-468$.

Platt, H. M., 1978. Assessment of the macrobenthos in an Antarctic environment following recent pollution abatement. - Mar. Pollut. Bull. 9, 149-153.

Platt, H. M., 1979. Sedimentation and the distribution of organic matter in a sub-Antarctic marine bay. - Estuar. coast. mar. Sci. 9, 51-63.

Platt, H. M. \& Mackie, P. R., 1979. Analysis of aliphatic and aromatic hydrocarbons in Antarctic marine sediment layers. - Nature, Lond. 280, 576-578.

Reed, W. E. \& Kaplan, I. R., 1977. The chemistry of marine petroleum seeps. -J. geochem. Explor. 7. 255-293. 
Wakeham, S. G., 1976. A comparative survey of petroleum hydrocarbons in lake sediments. - Mar. Pollut. Bull. 7, 206-211.

Whittle, K., Mackie, P. R. \& Hardy, R., 1974. Hydrocarbons in the marine ecosystem. - S. Afr. J. Sci. $70,141-144$.

Whittle, K. J., Mackie, P. R., Hardy, R., McIntyre, A. D. \& Blackman, R. A. A., 1977. The alkanes of marine organisms from the UK and surrounding waters. - Rapp. P.-v. Réun. Cons. perm. int. Explor. Mer 171, 72-78.

Windsor, J. G. \& Hites, R. A., 1979. Polycyclic aromatic hydrocarbons in Gulf of Maine sediments and Nova Scotia soils. - Geochim. cosmochim. Acta. 43, 27-33. 